\title{
Inappropriate sexual behaviour due to frontal dementia
}

\section{Alper Evrensel, ${ }^{1}$ Nevzat Tarhan, ${ }^{1}$ Mehmet Emin Ceylan, ${ }^{2}$ Gökçe Cömert ${ }^{2}$}

${ }^{1}$ Department of Psychiatry, Uskudar University, İstanbul, Turkey

${ }^{2}$ Uskudar University, İstanbul, Turkey

\section{Correspondence to} Dr Alper Evrensel, alperevrensel@gmail.com

\section{Accepted 9 January 2015}

CrossMark

\section{To cite: Evrensel $A$} Tarhan N, Ceylan ME, et al. BMJ Case Rep Published online: [please include Day Month Year] doi:10.1136/ bcr-2014-207864

\section{DESCRIPTION}

Three years ago, a 55-year-old man, a teacher, was involuntarily brought to our outpatient psychiatry clinic by his wife. He had agreed to be examined because of his wife's divorce request. He had no symptoms and no insight about his condition during the examination. According to his wife, he had started to spend more time on the computer using social media (Facebook, etc) to chat with women whom he did not know before and was staying up all night. He had an increased demand for sexual intercourse from his wife and had started to watch pornography. Their frequency of sexual intercourse was once or twice a week previously. He masturbated frequently indifferent to whether his wife or anyone else saw him. His wife

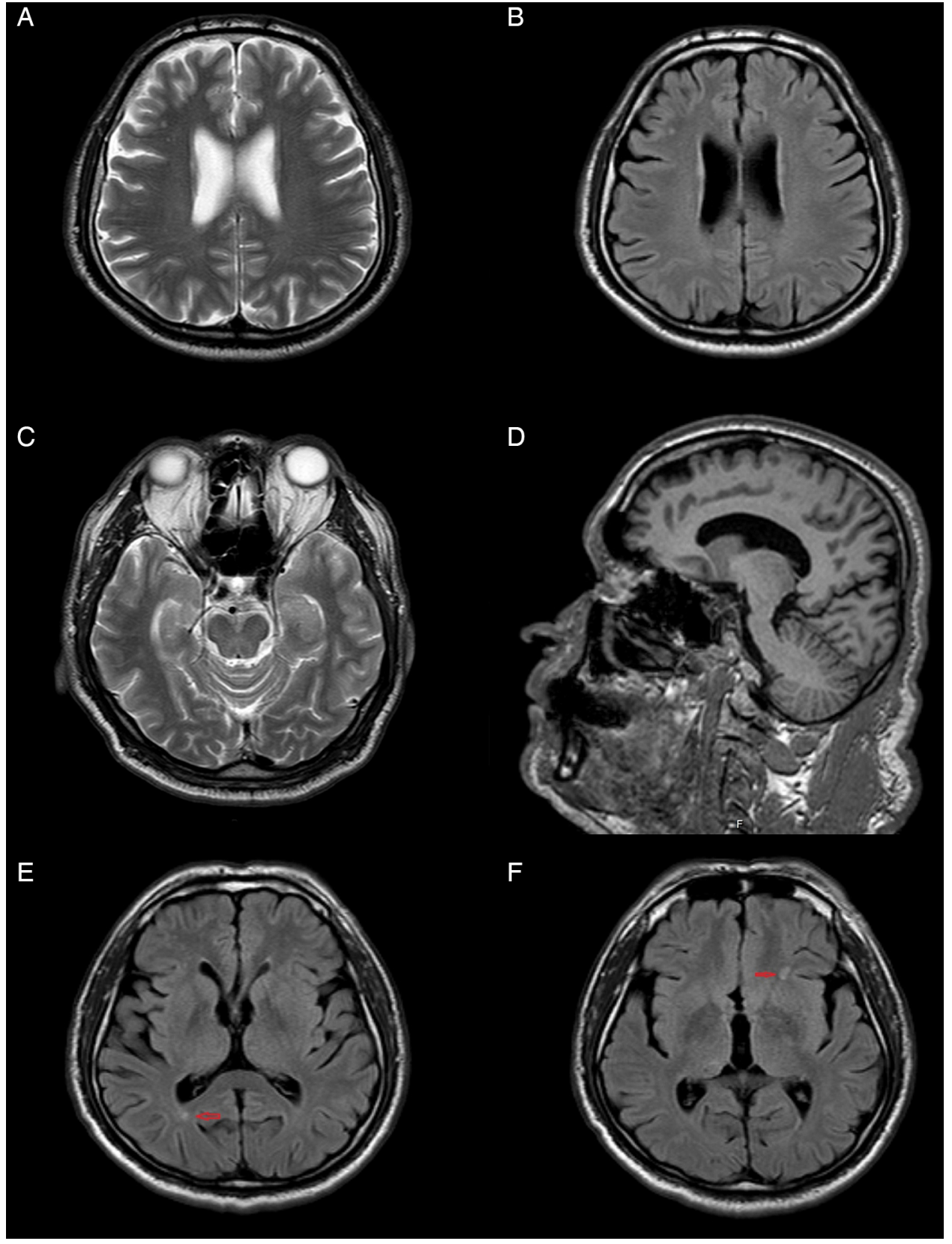

Figure 1 ( $A, B$ and $D) M R I$ of the brain showing bilateral frontal atrophy. (C) Temporal lobes are normal. (E and F) A few areas of gliosis on frontal and occipital lobes (red arrows). 


\section{Z Scored FFT Summary Information}
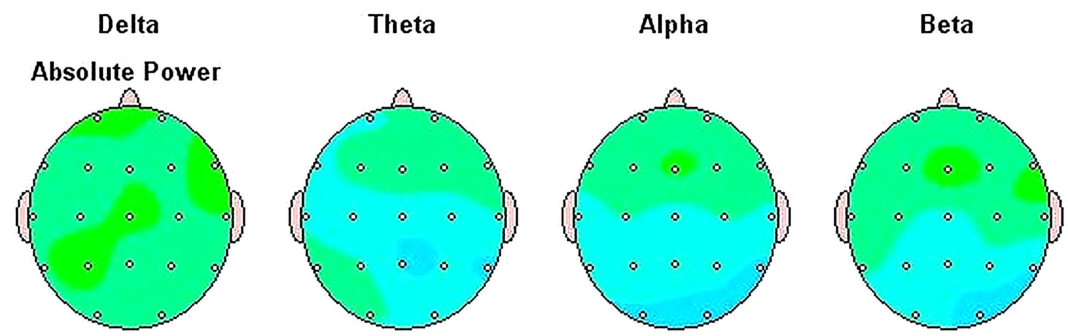

High Beta
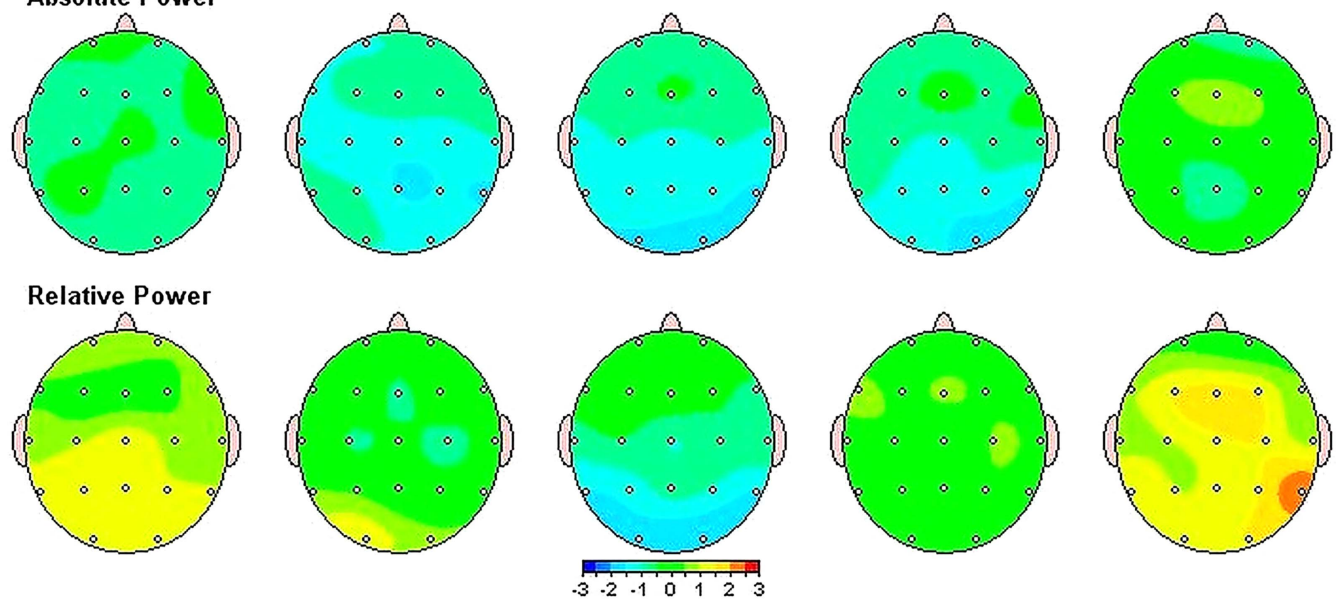

Figure 2 No paroxysmal activity was found in quantitative EEG.

found this 'incompatible with his age and strange'. Neither the patient nor his wife reported any cognitive decline. The patient had no previous history of psychiatric disorder. He had a diagnosis of obstructive sleep apnoea syndrome for which continuous positive airway pressure therapy was suggested; however, he did not comply with it. Bipolar affective disorder, schizophrenia, organic psychosis and dementia were considered in his differential diagnosis. After psychiatric examination, MRI of the brain and quantified EEG (QEEG) were taken. Brain MRI revealed focal frontal cortical atrophy and multiple gliotic foci (figure 1). No paroxysmal activity was found in QEEG (figure 2). His Mini-Mental State Examination (MMSE) score was 28/30. His frontal behaviour inventory (FBI) score was 33 (cut-off score: 27). He was started on risperidone $1.5 \mathrm{mg}$ /day and donepezil $10 \mathrm{mg} /$ day. During follow-up, his disinhibition declined. His family was given psycho-education regarding the disinhibition symptoms and possible progress of the dementia syndrome and further psycho-education was given especially to his wife to prevent caregiver's burn-out. Three years later, the patient's FBI score was decreased to 4 points and MMSE score to 27. Hypersexuality and inappropriate sexual behaviour (ISB) can often be observed in patients with dementia syndromes and especially in those with frontotemporal dementia (FTD). ${ }^{1}$ Hypersexuality and ISB without cognitive dysfunction may be the first signs of $\mathrm{FTD}^{2}$ and therefore differential diagnosis of FTD should be considered in patients presenting with disinhibition symptoms that necessitate brain MRI evaluation.

\section{Learning points}

- Hypersexuality and inappropriate sexual behaviour (ISB) may be the first symptoms of early onset frontal dementia.

- Frontal cortical brain atrophy on MRI is important for diagnosis.

- ISB may be under control with risperidone and olanzapine treatment.

Contributors AE and NT made the diagnosis, and carried out management and follow-up. AE carried out the literature review. MEC supervised and critically reviewed the article for intellectual content. AE drafted the manuscript and GC revised it.

Competing interests None.

Patient consent Obtained.

Provenance and peer review Not commissioned; externally peer reviewed.

\section{REFERENCES}

1 Abdo CH. Sexuality and couple intimacy in dementia. Curr Opin Psychiatry 2013;26:593-8.

2 Bardell A, Lau T, Federoff JP. Inappropriate sexual behavior in a geriatric population. Int Psychogeriatr 2011;23:1182-8. 
Copyright 2015 BMJ Publishing Group. All rights reserved. For permission to reuse any of this content visit http://group.bmj.com/group/rights-licensing/permissions.

BMJ Case Report Fellows may re-use this article for personal use and teaching without any further permission.

Become a Fellow of BMJ Case Reports today and you can:

- Submit as many cases as you like

- Enjoy fast sympathetic peer review and rapid publication of accepted articles

- Access all the published articles

- Re-use any of the published material for personal use and teaching without further permission

For information on Institutional Fellowships contact consortiasales@bmjgroup.com

Visit casereports.bmj.com for more articles like this and to become a Fellow 